\title{
EARLY PREVENTION OF OCCLUSAL DISORDERS OF DENTAL ARCHES
}

\author{
K.Z. Oleksyn, M.M. Rozhko
}

Department of Dentistry of the Institute of Postgraduate Education, Ivano-Frankivsk National Medical University, Ivano-Frankivsk, Ukraine

Email: hrystya15@yahoo.com

\author{
РАННЯ ПРОФІЛАКТИКА ОКЛЮЗІЙНИХ ПОРУШЕНЬ ЗУБНИХ РЯДІВ \\ Х.З. Олексин, М.М. Рожко \\ Кафедра стоматології ПО (зав. каф. - проф. Палійчук І.В.) \\ Івано-Франківського національного медичного університету, Івано-Франківськ, Україна \\ hrystya15@yahoo.com
}

\begin{abstract}
Occlusion is the joining of dental arches or individual groups of teeth over longer or shorter periods of time. Dental caries is one of the main factors of occlusal disorders. In economically developed countries, it affects $95-98 \%$ of the population. Dental caries results in changing location of occlusal contact points and is the cause of atypical mandibular movements. As a result, occlusal overloading and trauma are observed.

The objective of the research was to carry out early prevention of occlusal disorders in patients with carious lesions using modern restorative methods.

Materials and Methods. There were examined 90 first-/second-/third-year students of the Ivano-Frankivsk National Medical University at the age of 17-20 years living in the regions with low fluoride level in order to prevent occlusal disorders using the methods of restorations of the affected occlusal surfaces considering functional anatomy and subsequent checking of occlusal relationships with the help of the T-Scan Novus occlusal analysis system. Among them, 45 students were diagnosed with fissure caries of the first molars, 45 students underwent the restoration of the first molars without considering functional anatomy. Treatment was carried out by the methods of direct and indirect restorations.

Results. The paper contains the results of redistribution of occlusal contacts in carious lesions of the first molar (decrease in the occlusal load on the affected tooth, occurrence of overloading on the tooth with larger chewing area) and restoration of the first molar without considering the principles of functional anatomy (bite force directly on the tooth restored). Further restorations of the chewing surfaces of the first molars considering the occlusal determinants led to an even distribution of the occlusal force on the molars.

Conclusions. The results of our study demonstrated the effectiveness of the developed treatment and prevention complex.

Keywords: Occlusal Disorders; Analysis of Occlusion; Tooth Restoration; Prevention of Occlusal Disorders.

Резюме. Оклюзія - це змикання зубних рядів або окремих груп зубів протягом більшого чи меншого відрізку часу. Одним із факторів оклюзійних порушень $є$ карієс. В економічно розвинутих країнах ураженість населення сягає 95-98\%. Каріозний процес викликає зміни розташування точок в оклюзійному контакті, що є причиною виникнення атипових рухів нижньої щелепи. Як наслідок, спостерігається перевантаження зуба й угворення оклюзійної травми.

Мета нашого дослідження полягала в профілактиці оклюзійних порушень методом реставраційного відновлення уражених жувальних поверхонь з урахуванням функціональної анатомії та подальшій перевірці оклюзійних співвідношень 3 допомогою комп'ютеризованої системи T-Scan Novus. Для цього ми обрали 90 студентів 1-3 курсів ІФНМУ у віці 17-20 років, які проживають у регіонах з низьким рівнем фтору, з яких у половини наявні каріозні ураження перших молярів, а в інших 45-ти - реставраційні відновлення проведені без урахування оклюзійних детермінант. Лікування проводилось методами прямого й непрямого реставраційного відновлення оклюзійних поверхонь.

У статті наведені результати перерозподілу оклюзійних контактів при каріозному ураженні першого моляра (зменшення жувального навантаження на ураженому зубі, виникнення перенавантаження на зубі із більшою площею оклюзійної поверхні) та реставраційному відновленні першого моляра без урахування вимог функціональної анатомії (акцент оклюзії виникає безпосередньо на ньому). Подальше відновлення жувальних поверхонь уражених зубів з урахуванням оклюзійних детермінант та повторний аналіз оклюзії показали рівномірних розподіл жувального тиску на молярах. Отримані дані свідчать про ефективність створеного лікувальнопрофілактичного комплексу.
\end{abstract}

Ключові слова: оклюзійні порущення, аналіз оклюзії, реставраційні відновлення, профілактика оклюзійних порущень.

Problem Statement and Analysis of the Latest Research

Occlusion, in a dental context, is the harmony between dental arches, the temporomandibular joint (TMJ) and the neuromuscular system (masticatory muscles). There are static occlusion and dynamic occlusion. Static occlusion refers to contacts between the teeth when the jaw is closed and stationary. According to Angle's classification, there are three classes of malocclusion. This classification is based on molar relation. Dynamic occlusion refers to occlusal contacts occurring during movement of the mandible [5, 6, 8, 9, 11$]$.

A pair of the antagonist teeth form the functional complex, which includes a certain number of basic elements for stable jaw closure and performance of functional movements. Centric jaw relation (CJR) is the position of functional comfort for the components of the masticatory apparatus.

CJR contacts are critical to achieve jaw closure. Their location on the distolingual cusp ridge of the mandibular first molars and the mesiolingual cusp ridge of the maxillary first molars is considered perfect, as at this position the lower jaw is able to move forward and upward until the intercuspal relation is achieved. According to foreign studies, in case of cuspfossa occlusion, maximum bite force was the highest on the 
molars: $13.3 \% \pm 4.3$ and $13.6 \% \pm 5.4$ - on the first molars, $15.7 \% \pm 7.1$ and $18.7 \% \pm 7.5-$ on the second ones.

The starting point of CJR in oral cavity was found to appear on different teeth. Such position of CJR contacts is considered as premature contacts $[2,3,6,10]$.

Premature occlusal contacts form a variety of mandibular displacements during jaw closure under the influence of directing occlusal surfaces [3].

The alteration of occlusal relationships is observed in many dental diseases resulting in the occurrence of pathological processes in the masticatory apparatus $[1,5]$.

Dental caries is one of the main factors of occlusal problems that results in changing location of occlusal contact points and is the cause of atypical mandibular movements. As a result, occlusal overloading and trauma are observed [1, 4-7, 11].

The occlusal surfaces of the first molars are the most vulnerable for caries process. As the position of the first molars determines the relationship between dental arches (Angle's classification) and the height of centric occlusion, carious lesions of their surfaces are the cause of a number of complications, supracontacts on the intact teeth and lead to an alteration of both static and dynamic occlusions being causative and concomitant factors in the occurrence of changes in the TMJ $[1,5]$.

The methods of direct or indirect restorations without considering the determinants of occlusion are often used to treat carious lesions of tooth surface. The shape of the tooth, contacts with adjacent teeth and antagonists are the main occlusal determinants, that provide chewing, aesthetics, pronunciation and protection. The ignorance of these requirements of functional anatomy leads to occlusal trauma (occlusal overloading) $[2,10]$.

The objective of the research was to carry out early prevention of occlusal disorders of the teeth with carious lesions using modern restorative methods.

\section{Materials and Methods}

To determine occlusal disorders in carious lesions and to study the correlation between them, we examined 90 first-/ second-/third-year students of the Ivano-Frankivsk National Medical University (45 students were diagnosed with fissure caries of the first molars, 45 students underwent the restoration of the first molars without considering functional anatomy) with the help of the T-Scan Novus occlusal analysis system. It allowed us to visualize the contacts occurring between the teeth of the upper and lower jaws, time and sequence of contact occurrence, the location and the trajectory of force center (balance between the right and left sides) as dynamic 2D and 3D images.

The prevention of occlusal disorders was performed by the methods of direct and indirect restorations considering the determinants of occlusion with subsequent conducting computerized analysis of occlusion before, immediately after and 6 months after treatment.

Statistical analysis of the data distribution using the Shapiro-Wilk W test showed that most of the received measurements did not correspond to the Gaussian (normal) distribution $(\mathrm{p}<0.05)$. Therefore, to describe the typical values (a measure of central tendency), the median (Me) and the interquartile range (lower quartile-LQ, upper quartile-UQ) were selected. Accordingly, statistical significance of the difference in the data between the comparison groups was estimated by non-parametric methods: within the group for comparison with the data before treatment - the criterion of signs; between separate groups - Mann-Whitney U test.

\section{Results and Discussion}

The data obtained using the T-Scan Novus system showed that, in dental caries of the first molar (Fig. 1a), the highest bite force was observed on the adjacent second molar 17.2 (15.1$22.9) \%$ and the first molar antagonist $16.1(12.8-17.5) \%$. On the opposite side, in the area of posterior teeth, there were no pronounced occlusal interferences, fluctuation ranged from $11.2(6.7-11.8) \%$ to $13.6(11.2-16.1) \%$ on the first molars and from $13.2(11.4-15.2) \%$ to $14.1(12.1-18.2) \%$ on the second ones.

When the first molar was restored without considering the principles of functional anatomy (Fig. 1b), occlusal overloading occured directly on this tooth $18.7(17.7-21.4) \%$ and the opposite one 17.1 (15.4-17.9)\%. Bite force was evenly distributed on the adjacent posterior tooth $13.4(12.1-14.5) \%$ and the antagonist $14.2(13.9-14.8) \%$, as well as on the molars on the opposite side of the jaw $(12.5(12.3-12.9) \%-12.7(12.4-12.9) \%$ - the firstmolars, $14.0(13.6-14.2) \%$ - 14.1 (13.8-14.3)\% - the second molars).

The results immediately after restoration of cariuos first molar (Fig. 2a) indicated an even distribution of the occlusal load on the molars, namely the increase in bite force was directly proportional to the increase in the chewing surface of the tooth. Bite force on the restored molar increased to $12.6(12.2-13.2) \%$ $(\mathrm{p}<0.001)$ and decreased to $14.1(12.8-14.8) \%(\mathrm{p}<0.001)$ on the adjacent second molar. On the antagonist teeth, the occlusal force was $13.8(12.4-15.0) \%(\mathrm{p}<0.05)$ and $14.8(12.1-17.5) \%$ $(\mathrm{p}<0.01)$, respectively.

The results of repeated analysis of occlusion 6 months after restoration did not demonstrate any changes (Fig. 2b). There was an even distribution of the occlusal load on the molars: from $12.6(12.3-13.1) \%(\mathrm{p}<0.001)$ to $13.7(12.4-14.9) \%$ $(\mathrm{p}<0.001)$ on the first molars and from $13.9(12.5-14.5) \%$ $(p<0.001)$ to $14.1(13.1-15.2) \%(p>0.05)$ on the second molars.

The results of occlusal analysis immediately after (Fig. 3a) and 6 months after (Fig. 3b) retreatment of the first molar considering the principles of functional anatomy demonstrated a reduction in the occlusal force on it to 12.4 (12.3-12.6)\% $(p<0.001)$ and an even distribution of the force on the teeth.

Having analyzed the data obtained and the studies of foreign authors [10] regarding the occlusal load on the intact first molars $(13.3 \% \pm 4.3$ and $13.6 \% \pm 5.4)$ we can assume the following: carious lesion of the first molar led to redistribution of occlusal contacts (a decrease in the occlusal load on the affected tooth to $8.2(6.7-10.1) \%$ ), i.e., the occlusal load was transmitted to the tooth with a large occlusal surface area, namely the second molar (increased to 17.2(15.1-22.9)\%).

The restorations of the first molar without considering the principles of functional anatomy caused the occurrence of supracontacts $(18.7(17.7-21.4) \%)$; the similar situation was observed on the antagonist tooth (17.1 (15.4-17.9)\%). Computer analysis of occlusion using the T-Scan Novus system showed that restorations of the chewing surfaces of the first molars considering the occlusal determinants led to an even distribution of the occlusal load on the molars (on the restored tooth, the occlusal load increased to $12.6(12.3-13.1) \%$, on the adjancent 

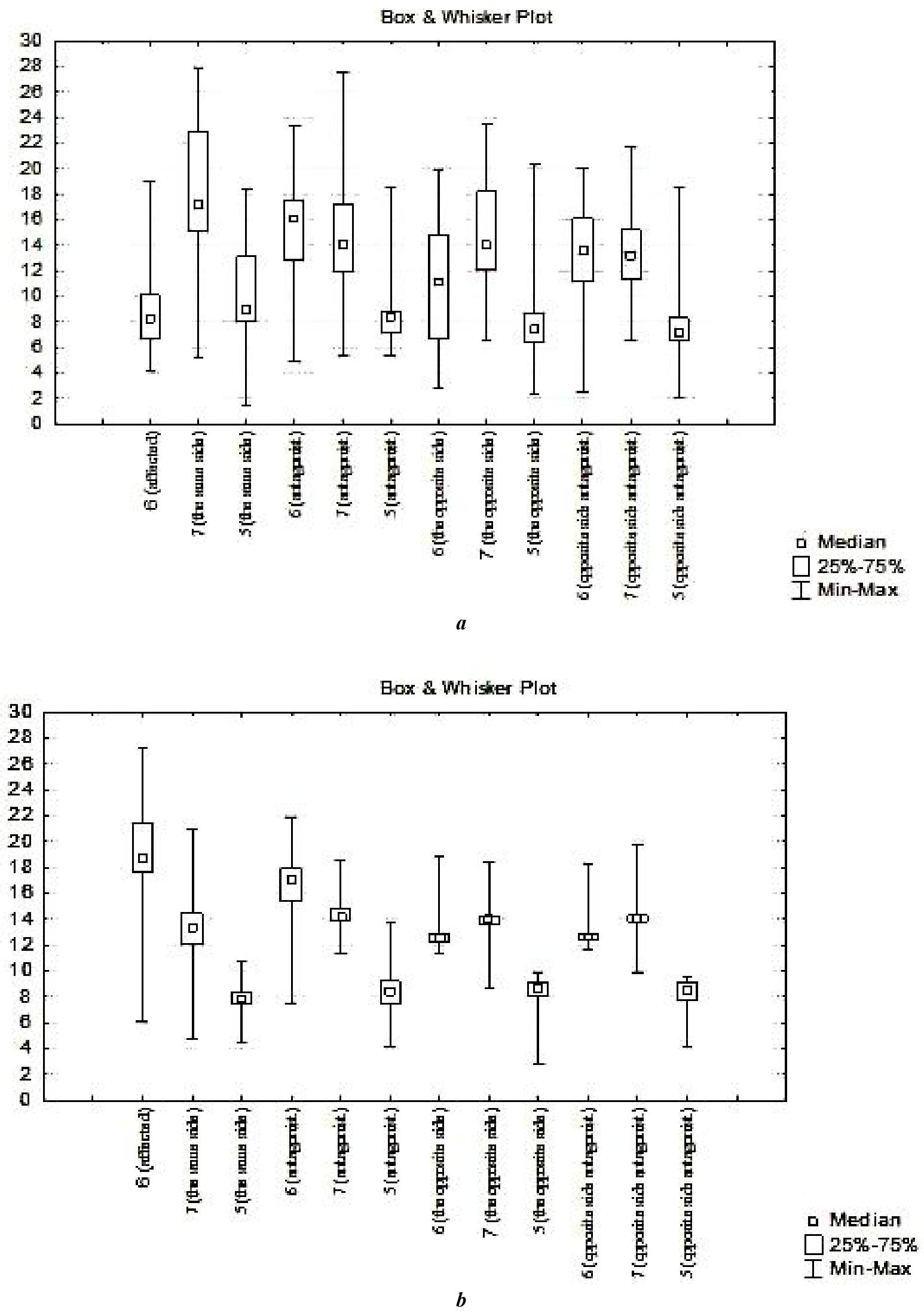

Fig.1. Median values of bite force in 90 students $(45$ students with dental caries of the first molar (a) and 45 students with inadequate restoration of the first molar (b) 


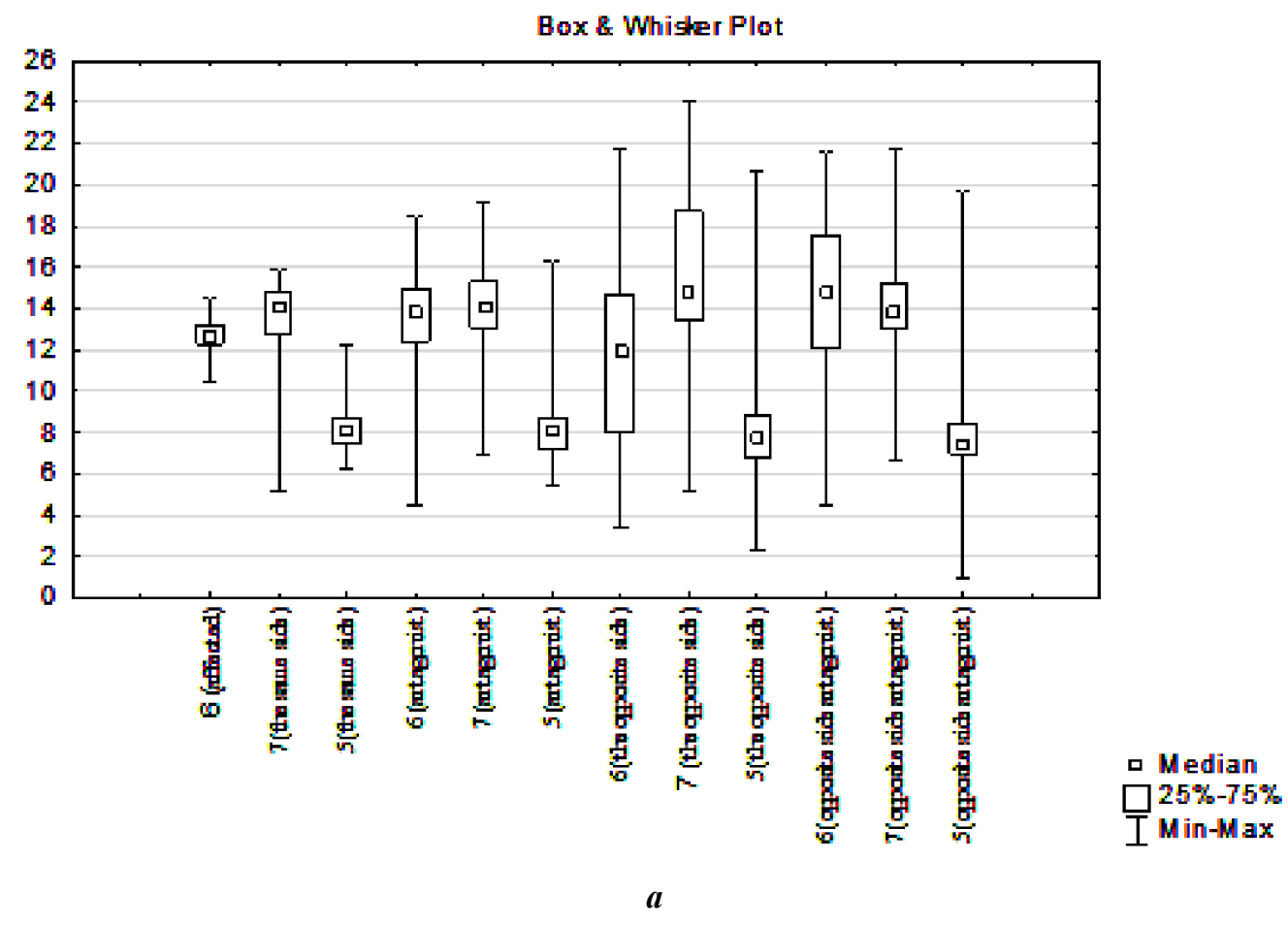

Box \&. Whisker Plot

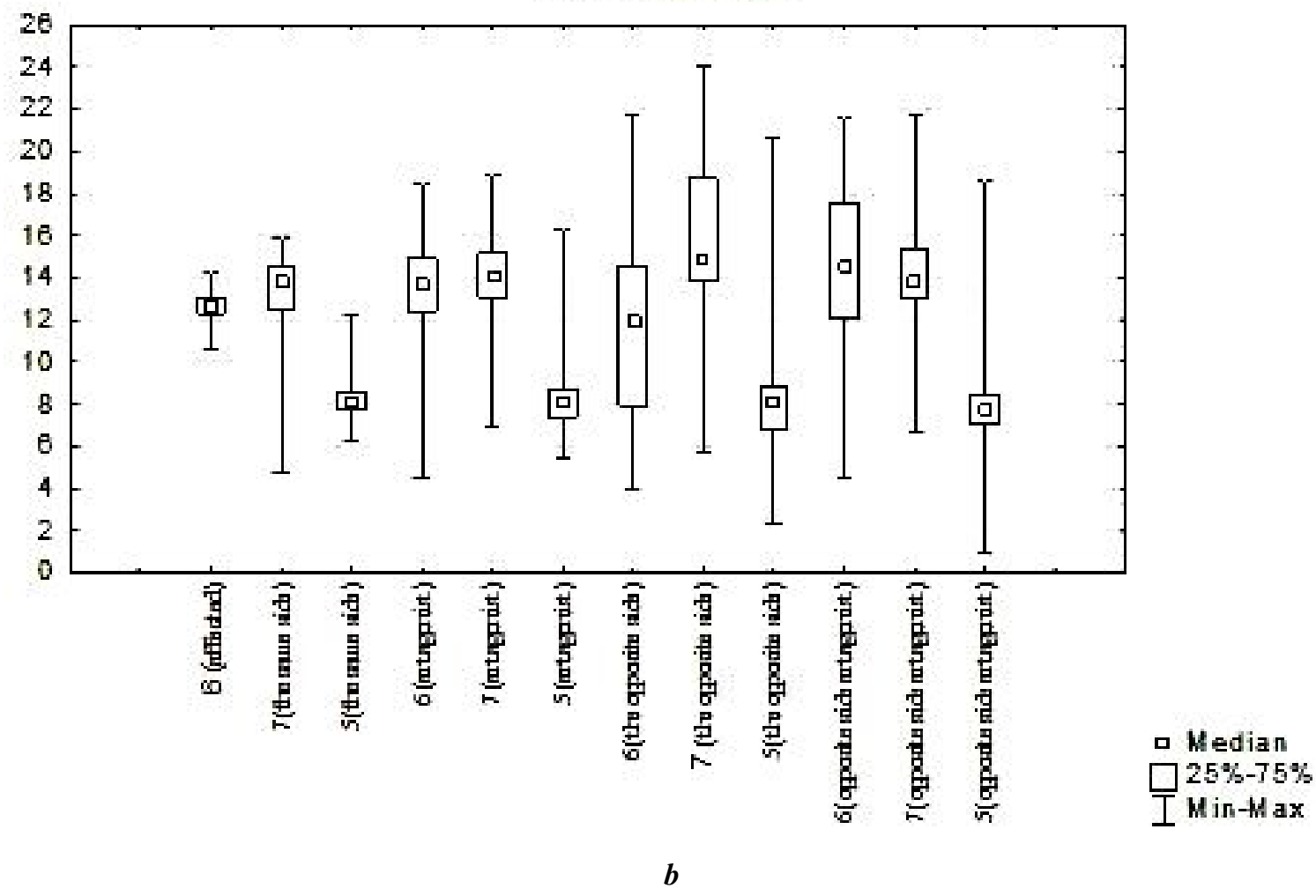

Fig. 2. Median values of bite force in 45 students immediately after (a) and 6 months $(b)$ after treatment of carious first molar 

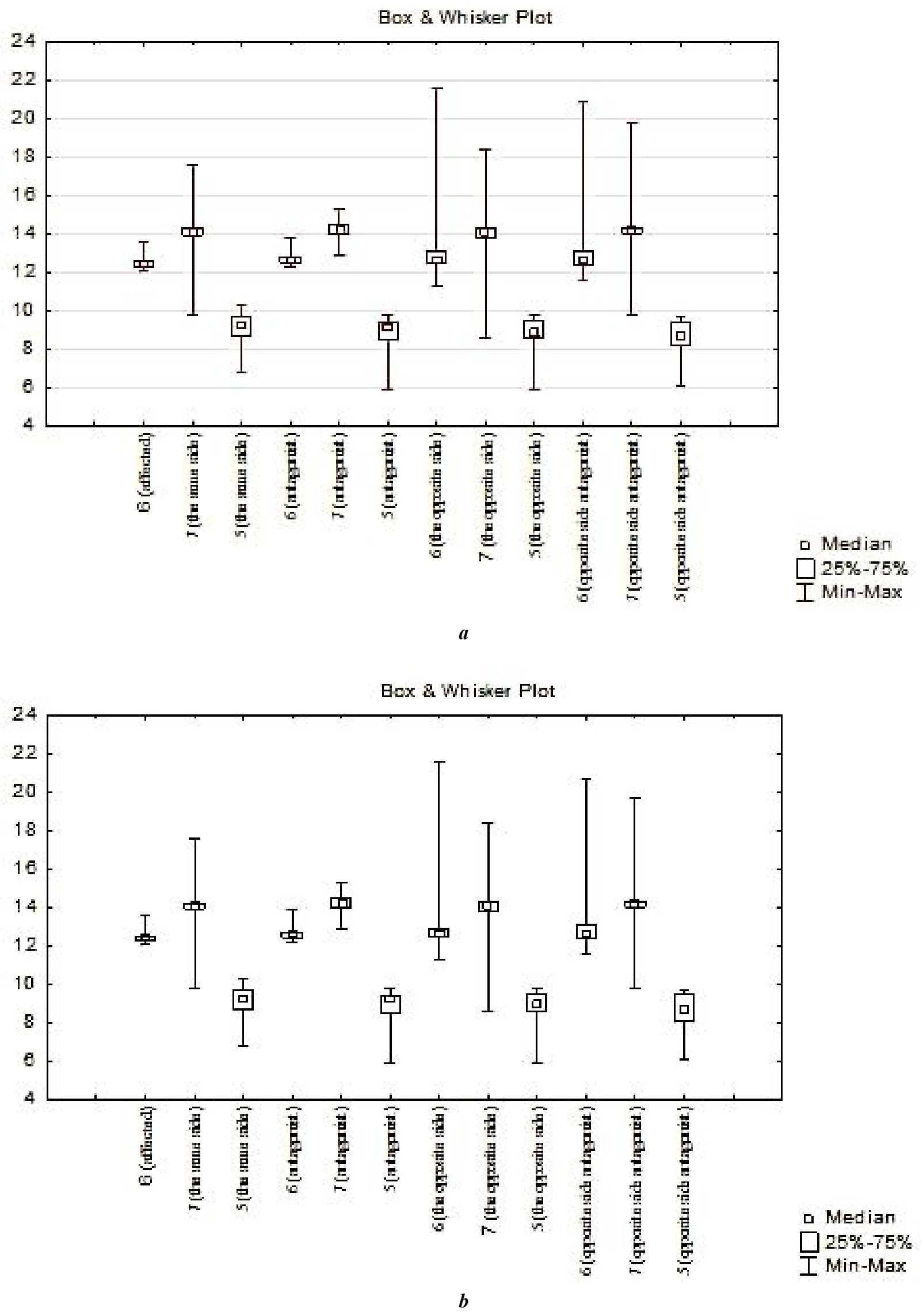

Fig. 3. Median values of the occlusal load on the teeth immediately after (a) and 6 months after $(b)$ retreatment of the first molar 
molars, it decreased to $13.9(12.5-14.5) \%$; on the retreated first molars, bite force decreased to $12.4(12.3-12.5) \%$ and increased to 14.1 (13.9-14.2)\% on the adjancent second molars).

The results obtained complemented the publications on the mechanism of occurence and correlation between occlusal disorders and carious disease, which indicated that the teeth with carious lesions have signs and symptoms of occlusal overloading.

\section{Conclusions}

The data of computer analysis obtained with the help of TScan Novus system showed the occurrence of occlusal overloading on the posterior teeth with carious lesions of the first molar or in case of its restoration without considering the principles of functional anatomy. The restoration of the chewing surfaces of affected teeth considering the occlusal determinants and computerized repeated analysis of occlusion showed an even distribution of the occlusal force on the molars. The results of our study demonstrated the effectiveness of the developed treatment and prevention complex.

\section{Prospects for Further Research}

The study of occurrence of occlusal disorders in patients with carious process in two or more teeth, or missing teeth and the development of treatment and prevention methods are promising.

\section{Informed Consent}

Informed consent was obtained from all the participants.

\section{Financial Disclosure}

The authors declared no financial support.

Conflict of Interest

The authors stated no conflict of interest.

\section{References}

1. Bragareva NV. Effektivnost obsledovaniya i lecheniya patsientov s razlichnymi faktorami kompensatsiyi okklyuzionnykh vzaimootnosheniy pri fiziologicheskoy okklyuziyi [dissertatsiya].
Stavropol; c2014. $130 \mathrm{p}$.

2. Douson PE. Funktsionalnaya okklyuziya: ot visochnonizhnechelyustnogo sustava do planirovaniya ulybki. Moscow: Prakticheskaya meditsina; 2016;1(1):15-22.

3. Zhegulovych ZYe. Clinico-instrumental analysis of the sequence of formation of dental occlusal contacts during jaws closing. Medychna nauka Ukraiiny. 2015;11(1-2):69-74. [published in Ukrainian]

4. Zhegulovych ZYe. Clinical behaviour of dental occlusion after the restoration at the conformative approach. Novyny stomatolohii. 2015;2(83):18-23. [published in Ukrainian]

5. Zakharova HYe. Patohenez, profilaktyka ta likuvannia okliuziinykh porushen $\mathrm{u}$ osib $\mathrm{z}$ vtratoiu pershykh postiinykh moliariv [avtoreferat]. Kyiv: NMU im. Bohomoltsia. c2009. 20p.

6. Mamedova LA. Pod gnetom okklyuziyi. Stomatolog Info. 2016;11(12):22-24.

7. Nespriadko VP, Skrypnyk YL, Tereshchuk EH et al. Analiz dynamiki izmeneniya pokazateley metoda otsenki funktsionalnoy okklyuziyi T-Scan u patsientov s okklyuzionnymi narusheniyami, kotorye voznikli ili byli sprovotsirovany $\mathrm{v}$ rezultate nekorrektnykh stomatologicheskikh vmeshatelstv. Sovremennaya ortodontiya. 2016;1:35-37.

8. Semenenko YuI, Semenenko IP, Yerys LB. Elektromiohrafichnyi kontrol reabilitatsii khvoroho $\mathrm{z}$ chastkovoiu vtratoiu zubiv, uskladnenoiu patolohichnym styranniam, vtorynnoiu deformatsiieiu zubiv ta znyzhenym prykusom. Ukrainskyi stomatolohichnyi almanakh. 2013;4:93.

9. Sivovol SI. Okklyuziya zubov i zhevatelnaya effektivnost. Stomatolog Info. 2016; 11-12:12-13.

10. Ma FF, Hu XL, Li JH, Lin Y. Normal occlusion study: using T-Scan III occlusal analysis system. Zhonghua Kou Qiang Yi Xue Za Zhi (Chinese journal of stomatology) 2013 Jun [cited 2013 Oct 13]; 48(6):363-7. https://doi.org/10.3760/cma.j.issn.10020098.2013.06.011

11. Ritter A, Boushell L, Walter R. Sturdevant's art and science of operative dentistry. 7th ed. Mosby; c2018. 39-40.

Received: 22.09 .2020

Revised: 05.11.2020

Accepted: 11.11.2020 